\title{
NOTE
}

\section{Microbial Transformation of Isopimpinellin by Glomerella cingulata}

\author{
Shinsuke Marumoto and Mitsuo Miyazawa* \\ Department of Applied Chemistry, Faculty of Science and Engineering, Kinki University (Kowakae, Higashiosaka-shi, Osaka 577-8502, JAPAN)
}

\begin{abstract}
Microbial transformation studies conducted on isopimpinellin (1) by the fungus Glomerella cingulata have revealed that 1 was metabolized to give the corresponding reduced acid, 5,8-dimethoxy-6,7furano-hydrocoumaric acid (2). The structure of metabolite 2 was elucidated by high-resolution mass spectrometry (HR-MS), extensive NMR techniques, including ${ }^{1} \mathrm{H}$ NMR, ${ }^{13} \mathrm{C}$ NMR, ${ }^{1} \mathrm{H}-{ }^{1} \mathrm{H}$ correlation spectroscopy (COSY), heteronuclear multiple quantum coherence (HMQC) and heteonuclear multiple bond coherence (HMBC). The biotransformed product 2 showed weak a in vitro $\beta$-secretase (BACE1) inhibitory effect.
\end{abstract}

Key words: biotransformation, isopimpinellin, Glomerella cingulate, $\beta$-secretase inhibitory activity.

\section{INTRODUCTION}

Isopimpinellin (5,8-dimethoxypsoralen, 1) occurs in a number of plants of the Apiaceae family and in some members of the Rutaceae ${ }^{1)}$. It is usually present together with 5- and 8-methoxypsoralen (5-MOP and 8-MOP) in plants such as celery, parsley, and the seeds of bishop's weed, Ammi majus. Compound 1 possesses antifungal, insecticidal, and insect antifeedant activities ${ }^{2-4)}$, as well as inhibition of cytochrome P450 enzymes activities ${ }^{5,6)}$. However to our knowledge, biotransformation of isopimpinellin has not been previously reported.

Biotransformation is today considered by synthetic organic chemists to be an economically competitive technology for the development of new production routes of fine chemical, pharmaceutical, and agrochemical compounds ${ }^{7)}$. Microorganisms are well known as efficient and selective catalysts. Previously, we studied the microbial transformation of furanocoumarins by Glomerella cingulat $a$ and evaluated the transformation products on the BACE1 inhibitory activity, ${ }^{8)}$. Therefore, it is envisioned that biotransformation of 1 may provide analogues which could be tested for new and improved activities. The goal of the present work was to transform isopimpinellin(1) using $G$. cingulata and to evaluate these compounds as BACE1 inhibitors (Fig. 1).<smiles></smiles><smiles>[R]OC(=O)CCc1c(O)c(OC)c2occc2c1OC</smiles>

Fig. 1 Chemical structures of isopimpinellin derivatives.

\section{EXPERIMENTAL PROCEDURE}

\subsection{General experimental procedures}

Thin layer chromatography (TLC) was performed on precoated plates ( $\mathrm{Si}$ gel $60 \mathrm{~F}_{254}, 0.25 \mathrm{~mm}$, Merck). The mobile phase was hexane-EtOAc (1:1). Compounds were visualized by spraying plates with $0.5 \%$ vanillin in $96 \% \mathrm{H}_{2} \mathrm{SO}_{4}$ followed by a brief heating. A SHIMAZU LC-10A HPLC system (SHIMAZU CO., LTD., Kyoto, Japan) comprised a quaternary solvent deliver system, an auto-sampler, a column temperature controller and a photo diode array (PDA) coupled with an analytical works station. A YMCPack ODS-AQ $(4.6 \mathrm{~mm} \times 250 \mathrm{~mm}, 5 \mu \mathrm{m}$ particle size, YMC Co., LTD., Japan) with a YMC-Pack ODS-AQ guard column (4.6 $\mathrm{mm} \times 23 \mathrm{~mm}, 5 \mu \mathrm{m}$ particle size, YMC Co., LTD., Japan) was used. The chromatographic parameters were as follows: solvent A acetonitrile, solvent B water, both modified with $0.1 \%(\mathrm{v} / \mathrm{v})$ acetic acid. The gradient was set as

\footnotetext{
*Correspondence to: Mitsuo Miyazawa, Department of Applied Chemistry, Faculty of Science and Engineering, Kinki University, Kowakae, Higashiosaka-shi, Osaka 577-8502, JAPAN

E-mail: miyazawa@apch.kindai.ac.jp

Accepted June 13, 2011 (recived for review May 25, 2011)

Journal of Oleo Science ISSN 1345-8957 print / ISSN 1347-3352 online

http://www.jstage.jst.go.jp/browse/jos/ http://mc.manusriptcentral.com/jjocs
} 


\section{S. Marumoto and M. Miyazawa}

follows: $20 \%$ A for $10 \mathrm{~min}$ at $1.0 \mathrm{~mL} / \mathrm{min}, 20-70 \% \mathrm{~A}$ in 100 min at $1.0 \mathrm{~mL} / \mathrm{min}, 70 \% \mathrm{~A}$ for $10 \mathrm{~min}$ at $1.0 \mathrm{~mL} / \mathrm{min}$. The total runtime was $110 \mathrm{~min}$. The injection volume was 10 $\mu \mathrm{L}$. Electron-ionization mass spectrometry (EIMS), highresolution electron-ionization mass spectrometry (HREIMS) fast atom bombardment mass spectrometry (FABMS) and high-resolution fast atom bombardment mass spectrometry (HRFABMS) were obtained on a JEOL the Tandem Ms stationJMS-700 TKM. Nuclear magnetic resonance (NMR) spectra were recorded at 400 or $500 \mathrm{MHz}$ $\mathrm{MHz}$ for ${ }^{1} \mathrm{H}$ and 125 or $100 \mathrm{MHz} \mathrm{MHz}$ for ${ }^{13} \mathrm{C}$ on a JEOL ECA 500 or AL 400 spectrometer. Infrared(IR) spectra were determined with a JASCO FT/ IR-470 plus Fourier transform infrared spectrometer. A BACE1 (recombinant human BACE1) assay kit was purchased from PanVera Co., USA.

\subsection{Chemical}

Isopimpinellin(1) was synthesized according to the methods reported previously ${ }^{10)}$.

\subsection{Preculture of G. cingulata}

Spores of G. cingulata NBRC 5952 (NITE Biological Resource Center, Japan), which had been preserved on potato dextrose agar (PDA) at $4{ }^{\circ} \mathrm{C}$, were inoculated into $200 \mathrm{~mL}$ of sterilized culture medium (1.5\% saccharose, $1.5 \%$ glucose, $0.5 \%$ polypeptone, $0.05 \% \mathrm{MgSO}_{4} \cdot 7 \mathrm{H}_{2} \mathrm{O}$, $0.05 \% \mathrm{KCl}, 0.1 \% \mathrm{~K}_{2} \mathrm{HPO}_{4}$, and $0.001 \% \mathrm{FeSO}_{4} \cdot 7 \mathrm{H}_{2} \mathrm{O}$ in distilled $\mathrm{H}_{2} \mathrm{O}$ ) in a 500-mL shaking flask, and the flask was shaken (reciprocating shaker, $100 \mathrm{rpm}$ ) at $27^{\circ} \mathrm{C}$ for 3 days.

\subsection{Time course of biotransformation and quantification of metabolite}

Precultured $G$. cingulata $(3 \mathrm{~mL})$ was transferred into two 300-mL Erlenmeyer flasks containing $100 \mathrm{~mL}$ of medium and was stirred (ca. $120 \mathrm{rpm}$ ) for 3 days. After the growth of $G$. cingulata, 1 (10 mg, $46 \mu \mathrm{mol})$ in $0.5 \mathrm{~mL}$ of dimethyl sulfoxide (DMSO) was added into the medium, and cultivated for 7 more days. Every other day, $5 \mathrm{~mL}$ of the culture medium was extracted with EtOAc. This extract was analyzed by TLC and HPLC. The mobile phase and detector used were the same as above. The contents of these compounds were calculated by means of the absolute calibration curves. The time course of biotransformation is shown in Fig. 2.

\subsection{Preparative biotransformation of isopimpinellin (1).}

Precultured $G$. cingulata $(5 \mathrm{~mL})$ was transferred into a $500 \mathrm{~mL}$ Erlenmeyer flask containing $300 \mathrm{~mL}$ of medium. Cultivation was carried out at $27^{\circ} \mathrm{C}$ with stirring (ca. 120 $\mathrm{rpm}$ ) for 3 days. After the growth of $G$. cingulata, $50 \mathrm{mg}$ of 1 in $1.0 \mathrm{~mL}$ of dimethyl sulfoxide (DMSO) was added into the medium and cultivated for an additional 7 days, together with two controls, which contained either mycelia with

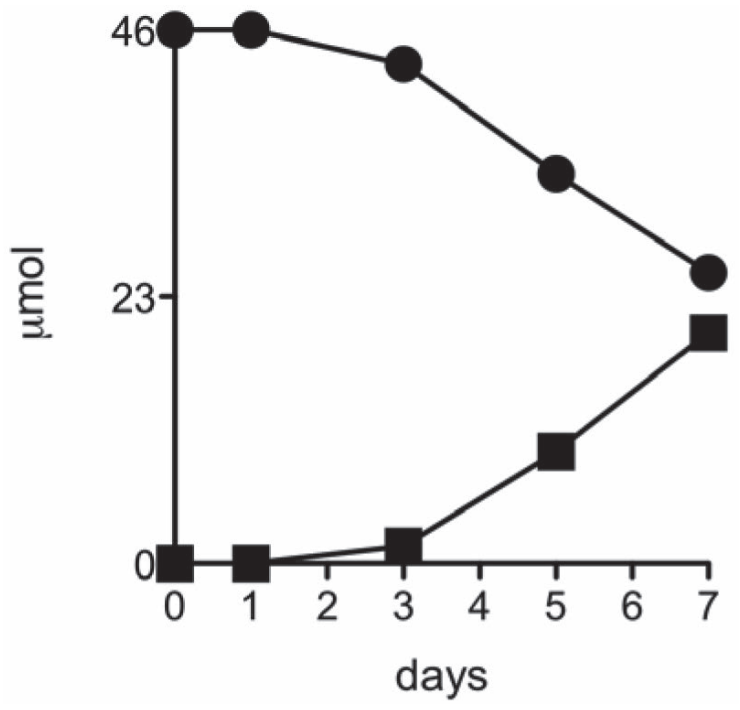

Fig. 2 Time course in the biotransformation of 1 by G. cingulata: $(\mathbf{O})$ isopimpinellin (1); ( $\mathbf{\square})$ metabolite 2.

medium or substrate dissolved in DMSO with medium. No metabolic product was observed in the two controls. After fermentation, the culture medium and mycelia were separated by filtration. The medium was saturated with $\mathrm{NaCl}$, and extracted with EtOAc. The mycelia were also extracted with EtOAc. Each EtOAc extract was combined, the solvent was evaporated, and a crude extract $(411 \mathrm{mg})$ was obtained. The extract was distributed between $5 \%$ $\mathrm{NaHCO}_{3}$ aq. and EtOAc, and the EtOAc phase was evaporated to give a neutral fraction $(256 \mathrm{mg}$ ). No metabolite was detected by TLC and HPLC. The alkali phase was acidified to $\mathrm{pH} 3$ with $1 \mathrm{~N} \mathrm{HCl}$ and distributed between water and EtOAc. The EtOAc phase was evaporated, and the acidic fraction (155 mg) was obtained. Metabolites were detected in the acidic fraction by TLC and HPLC. The acidic fraction was dissolved in acetone $(5 \mathrm{~mL})$, and $\mathrm{CH}_{2} \mathrm{~N}_{2}(1 \mathrm{~mL})$ was added to the fraction. The solution was evaporated, and the methylation fraction was obtained. The methylation fraction was subjected to flash silica-gel column chromatography (silica gel 60, 230-400 mesh, Merck)with a hexane- $\mathrm{Et}_{2} \mathrm{O}$ gradient (1:1) to yield compound $2 \mathrm{a}(23 \mathrm{mg})$. Compound $2 \mathrm{a}(20 \mathrm{mg})$ was dissolved in $\mathrm{MeOH}(1 \mathrm{~mL}), 1 \%$ $\mathrm{NaOH}(2 \mathrm{~mL})$ added to the solution, and the solution was refluxed for $30 \mathrm{~min}$. The solution was acidified to $\mathrm{pH} 3$ with $1 \mathrm{~N} \mathrm{HCl}$ and distributed between EtOAc and water. The EtOAc phase was evaporated to yield 2 (15 mg).

5,8-Dimethoxy-6,7-furano-hydrocoumaric acid (2)

Pale yellow powder; $\operatorname{IR}(\mathrm{KBr}) v_{\max } 3495$ and $1705 \mathrm{~cm}^{-1}$; ${ }^{13} \mathrm{C}$ and ${ }^{1} \mathrm{H}$ NMR shown as Table 1; HR-FABMS (pos) $\mathrm{m} / \mathrm{z}$ $267.0895[\mathrm{M}+\mathrm{H}]^{+}$(calcd. for $\left.\mathrm{C}_{13} \mathrm{H}_{15} \mathrm{O}_{6}, 267.0869\right)$.

5,8-Dimethoxy-6,7-furano-hydrocoumaric acid methyl ester (2a)

Pale yellow powder; IR $(\mathrm{KBr}) v_{\max } 3419$ and $1732 \mathrm{~cm}^{-1}$; 
Table 1 The ${ }^{13} \mathrm{C}$ and ${ }^{1} \mathrm{H}$ NMR spectroscopic data of compounds 1 and 2.

\begin{tabular}{|c|c|c|c|c|}
\hline \multirow[b]{2}{*}{ position } & \multicolumn{2}{|c|}{$1^{\mathrm{a}}$} & \multicolumn{2}{|c|}{$2^{\mathrm{b}}$} \\
\hline & $\delta_{\mathrm{C}}$ & $\delta_{\mathrm{H}}$ & $\delta_{\mathrm{C}}$ & $\delta_{\mathrm{H}}$ \\
\hline 2 & $159.8(\mathrm{C})^{\mathrm{c}}$ & & $174.7(\mathrm{C})$ & \\
\hline 3 & $112.7(\mathrm{CH})$ & $6.301 \mathrm{H}, d,(9.6)^{\mathrm{d}}$ & $34.3\left(\mathrm{CH}_{2}\right)$ & $2.422 \mathrm{H}, m$ \\
\hline 4 & $139.9(\mathrm{CH})$ & $8.131 \mathrm{H}, d,(9.6)$ & $20.4\left(\mathrm{CH}_{2}\right)$ & $2.882 \mathrm{H}, m$ \\
\hline $4 a$ & $106.9(\mathrm{C})$ & & $115.6(\mathrm{C})$ & \\
\hline 5 & $144.5(\mathrm{C})$ & & $147.2(\mathrm{C})$ & \\
\hline 6 & $114.6(\mathrm{C})$ & & $113.3(\mathrm{C})$ & \\
\hline 7 & $149.6(\mathrm{C})$ & & $147.4(\mathrm{C})$ & \\
\hline 8 & $127.4(\mathrm{C})$ & & $129.4(\mathrm{C})$ & \\
\hline $8 \mathrm{a}$ & $143.3(\mathrm{C})$ & & $145.6(\mathrm{C})$ & \\
\hline 9 & $146.5(\mathrm{CH})$ & $7.631 \mathrm{H}, d,(2.1)$ & $143.8(\mathrm{CH})$ & $7.541 \mathrm{H}, d,(2.3)$ \\
\hline 10 & $105.9(\mathrm{CH})$ & $7.001 \mathrm{H}, d,(2.1)$ & $105.6(\mathrm{CH})$ & $6.861 \mathrm{H}, d,(2.3)$ \\
\hline $5-\mathrm{OCH}_{3}$ & $61.0\left(\mathrm{CH}_{3}\right)$ & $4.173 \mathrm{H}, s$ & $60.9\left(\mathrm{CH}_{3}\right)$ & $3.873 \mathrm{H}, s$ \\
\hline $8-\mathrm{OCH}_{3}$ & $61.5\left(\mathrm{CH}_{3}\right)$ & $4.173 \mathrm{H}, s$ & $61.1\left(\mathrm{CH}_{3}\right)$ & $3.853 \mathrm{H}, s$ \\
\hline
\end{tabular}

\footnotetext{
${ }^{a}$ Measured at $100 \mathrm{MHz}$ for ${ }^{13} \mathrm{C}$ and $400 \mathrm{MHz}$ for ${ }^{1} \mathrm{H}$ in $\mathrm{CDCl}_{3}$.

${ }^{\mathrm{b}}$ Measured at $125 \mathrm{MHz}$ for ${ }^{13} \mathrm{C}$ and $500 \mathrm{MHz}$ for ${ }^{1} \mathrm{H}$ in Acetone- $d_{6}$.

${ }^{\mathrm{c}}{ }^{13} \mathrm{C}$ multiplicities were determined by DEPT $135^{\circ}$

${ }^{\mathrm{d}}$ The $J$ values are $\mathrm{Hz}$ in parentheses.
}

${ }^{1} \mathrm{H} \mathrm{NMR}\left(\mathrm{CDCl}_{3}, 500 \mathrm{MHz}\right) \delta 7.46(1 \mathrm{H}, \mathrm{d}, J=2.3 \mathrm{~Hz}, \mathrm{H}-9)$, $6.82(1 \mathrm{H}, \mathrm{d}, J=2.3 \mathrm{~Hz}, \mathrm{H}-10), 4.12\left(3 \mathrm{H}, \mathrm{s}, 8-\mathrm{OCH}_{3}\right), 3.97$ $\left(3 \mathrm{H}, \mathrm{s}, 5-\mathrm{OCH}_{3}\right), 3.69\left(3 \mathrm{H}, \mathrm{s}, \mathrm{COOCH}_{3}\right), 3.04(2 \mathrm{H}, \mathrm{m}, \mathrm{H}-4)$, $2.62(2 \mathrm{H}, \mathrm{m}, \mathrm{H}-3) ;{ }^{13} \mathrm{C} \mathrm{NMR}\left(\mathrm{CDCl}_{3}, 125 \mathrm{MHz}\right) \delta 174.5(\mathrm{C}$, C-2) 146.2 (C, C-5), 145.7 (C, C-7), 143.7 (C, C-8a), 142.7 (CH, C-9), 128.2 (C, C-8), 114.2 (C, C-4a), 113.0 (C, C-6), $104.7(\mathrm{CH}, \mathrm{C}-10), 60.9\left(\mathrm{CH}_{3}, 8-\mathrm{OCH}_{3}\right), 60.7\left(\mathrm{CH}_{3}, 5-\mathrm{OCH}_{3}\right)$ $51.7\left(\mathrm{CH}_{3}, \mathrm{COOCH}+{ }_{3}\right), 33.9\left(\mathrm{CH}_{2}, \mathrm{C}-3\right), 19.5\left(\mathrm{CH}_{2}, \mathrm{C}-4\right)$; EIMS $\mathrm{m} / \approx 280[\mathrm{M}]^{+}(38), 248(100), 206(77), 191(86), 163(33)$; HR-EIMS $m / z 280.0952[\mathrm{M}]^{+}$(calcd. for $\mathrm{C}_{14} \mathrm{H}_{16} \mathrm{O}_{6}$, 280.0947).

\section{$2.6 \beta$-Secretase (BACE1) enzyme assay}

The assay was carried out according to the supplied manual with modifications $(8,9)$. Briefly, a mixture of $10 \mu \mathrm{L}$ of assay buffer (50 mM sodium acetate, $\mathrm{pH} 4.5), 10 \mu \mathrm{L}$ of BACE1 $(1.0 \mathrm{U} / \mathrm{mL}), 10 \mu \mathrm{L}$ of the substrate $(750 \mathrm{nM}$ RhEVNLDAEFK-Quencher in $50 \mathrm{mM}$ ammonium bicarbonate), and $10 \mu \mathrm{L}$ of sample dissolved in 30\% DMSO was incubated for $60 \mathrm{~min}$ at room temperature in the dark. The mixture was irradiated at $550 \mathrm{~nm}$ and the emission intensity at $590 \mathrm{~nm}$ was recorded. The inhibition ratio was obtained by the following equation:

$$
\operatorname{Inhibition}(\%)=\left[1-\left\{\left(S-S_{0}\right) /\left(C-C_{0}\right)\right\}\right] \times 100
$$

where $C$ was the fluorescence of the control(enzyme, buffer, and substrate) after $60 \mathrm{~min}$ of incubation, $C_{0}$ was the fluorescence of control at zero time, $S$ was the fluorescence of the tested samples (enzyme, sample solution, and substrate) after incubation, and $S_{0}$ was the fluorescence of the tested samples at zero time. To allow for the quenching effect of the samples, the sample solution was added to the reaction mixture $C$, and any reduction in fluorescence by the sample was then investigated. All data are the mean of three experiments.

\section{RESULTS AND DISCUSSION}

Isopimpinellin(1) was administered to fungal cultures of G. cingulata, the cultures were incubated for 7 days. HPLC chromatograms of extracts from the cultures incubated with isopimpinellin(1)indicated that 1 was metabolized to 2 in $47 \%$ yield for 7 days (Fig. 2). Subsequently, to obtain sufficient quantities of each product for broth chemical characterization and bioassay, a larger scale mycelia incubated with 1 was performed, the culture was extracted as described in Materials and Methods, and methylated metabolite 2 (compound $2 \mathrm{a}$ ) was isolated. Metabolite 2 was obtained by the hydrolysis of $2 \mathrm{a}$. The structures of these compounds were determined by spectral data.

HR-FABMS of compound 2 showed $[\mathrm{M}+\mathrm{H}]^{+}$peaks at $\mathrm{m} / \approx 267.0895$ (calcd. for $\mathrm{C}_{13} \mathrm{H}_{15} \mathrm{O}_{6} 267.0869$ ), which established a molecular formula of $\mathrm{C}_{13} \mathrm{H}_{14} \mathrm{O}_{6}$. The presence of a broad absorption band at $3495 \mathrm{~cm}^{-1}$ and a strong absorption band at $1705 \mathrm{~cm}^{-1}$ in the IR spectrum. Comparing ${ }^{1} \mathrm{H}$ NMR data of 2 with those of 1 , the signals ascribed to the 


\section{S. Marumoto and M. Miyazawa}

$\beta$-enone system were found to be absent in 2 . Instead two sets of methylene protons were observed at $\delta_{\mathrm{H}} 2.87$ and $2.59 \mathrm{ppm}$, respectively. Methylene peaks at $\delta_{\mathrm{C}} 34.4$ and $26.4 \mathrm{ppm}$ were detected by ${ }^{13} \mathrm{C}$ NMR spectrum. This showed that some chemical changes have occurred on the lactone moiety of the coumarin ring, as no changes in NMR were detected for the benzofuran moiety of furanocoumarin. The chemical structure of 2 was shown to be identical to 5,8-dimethoxy-6,7-furano-hydrocoumaric acid(2). The protons and carbons assignments were unambiguously made from the H-H COSY, HMQC and HMBC spectra. This is the first report of the spectral data of 2 .

Previously, we had incubated furanocoumarins bergapten, with a methoxy group at $\mathrm{C}_{5}$ position, and xanthotoxin, with a methoxy group at the $\mathrm{C}_{8}$ position, by $G$. cingulata ${ }^{9)}$. In the biotransformation of bergapten and xanthotoxin, fungal reduction progressed not only bergapten but also xanthotoxin. In addition a demethylated product was produced as a minor metabolite in the biotransformation of xanthotoxin. The reduction product of 1 by $G$. cingulata was identified in this study. However a demethylated metabolite was not detected in this biotransformation. These results indicate that the presence of an alkoxy group at the $\mathrm{C}_{5}$ position was involved in the dealkylation of the alkoxy group at the $\mathrm{C}_{8}$ position in the furanocoumarin skeleton by G. cingulata.

Subsequently, the $\beta$-secretase (BACE1) inhibitory effects of compounds 1, 2, and 2a were evaluated to search for potential novel anti-Alzheimer agents. Compounds 1, 2, and 2 a showed weak inhibitory effects against BACE1. BACE1 inhibitory effects of compounds 1, 2, and 2a were $11.2,19.1$, and $20.9 \%$ at concentration of $0.5 \mathrm{mM}$, respectively.

In summary, the present study demonstrated that the fungus $G$. cingulata was able to transform isopimpinellin (1) to a corresponding reduced acid enzymatically. Since there are no reports on mammalian metabolites of isopimpinellin(1), the data on the microbial transformed product 2 may be useful for further pharmacological evaluation of 1 . They may also be used as analytical standards for detection in biological fluids.

\section{References}

1) Murray R. D.; Mendez J.; Brown S. A. The Natural Coumarins: Occurrence, Chemistry and Biochemistry. John Wiley \& Sons, Ltd., New York (1982).

2) Montagner C.; de Souza S. M.; Groposo C.; Delle M. F. S.; Elza F. A.; Smania A. Jr. Antifungal activity of coumarins. Z. Naturforsch., C: J. Biosci. 63, 21-28 (2008).

3) Miyazawa M.; Tsukamoto T.; Anzai J.; Ishikawa Y. Insecticidal effect of phthalides and furanocoumarins from Angelica acutiloba against Drosophila melanogaster. J. Agric. Food Chem. 52, 4401-4405 (2004).

4) Yajima T.; Munakata K. Phloroglucinol-type furocoumarins, a group of potent naturally-occurring insect antifeedants. Agric. Biol. Chem. 43, 1701-1706 (1979).

5) Cai Y.; Bennett D.; Nair R. V.; Ceska O.; AshwoodSmith M. J.; DiGiovanni J. Inhibition and inactivation of murine hepatic ethoxy- and pentoxyresorufin O-dealkylase by naturally occurring coumarins. Chem. Res. Toxicol. 6, 872-879(1993).

6) Uesawa Y.; Mohri K. Quantitative structure-activity relationship (QSAR) analysis of the inhibitory effects of furanocoumarin derivatives on cytochrome P450 3A activities. Pharmazie 65, 41-46 (2010).

7) Davis B. G.; Boyer V. Biocatalysis and enzymes in organic synthesis. Nat. Prod. Rep. 18, 618-640 (2001).

8) Marumoto S.; Miyazawa M. Biotransformation of isoimperatorin and imperatorin by Glomerella cingulata and $\beta$-secretase inhibitory activity. Bioorg. Med. Chem. 18, 455-459 (2010).

9) Marumoto S.; Miyazawa M. Biotransformation of bergapten and xanthotoxin by Glomerella cingulata. J. Agric. Food Chem. 58, 7777-7781 (2010).

10) Wulff H.; Rauer H.; Duering T.; Hanselmann C.; Ruff K.; Wrisch A.; Grissmer S.; Haensel W. Alkoxypsoralens, novel nonpeptide blockers of shaker-type $\mathrm{K}^{+}$channels: synthesis and photoreactivity. J. Med. Chem. 41, 4542-4549(1998). 